\title{
Requirements for M-Learning Activities
}

\author{
Ernane Rosa Martins ${ }^{1 *}$, Luis Manuel Borges Gouveia ${ }^{2}$ \\ ${ }^{1}$ Federal Institute of Education, Science and Technology of Goiás, Brazil \\ ${ }^{2}$ University Fernando Pessoa, Portugal
}

*Corresponding Author: Ernane Rosa Martins, Federal Institute of Education, Science and Technology of Goiás, Brazil

\begin{abstract}
To investigate different requirements related to m-learning projects, is important for the development and analysis of them. In this sense, this paper has presented the results of a literature review on requirements for mobile learning activities. Thus, it was selected as purchases related to the central scope of this study, through the scientific examination of articles, theses and national and international dissertations without the Bank of theses and periodicals of the Coordination of Improvement of Higher Education Personnel. Those identified and mapped can help teachers and other professionals to use m-learning more effectively in the educational context.
\end{abstract}

Keywords: Requirements, M-learning, Activities.

\section{INTRODUCTION}

Mobile learning or m-learning is the expression used to designate a new educational "paradigm", which is based on the use of mobile technologies. Thus, it is possible to call m-learning any form of learning through any small format devices, with autonomous and small size power supply, that is possible to accompany people anywhere and at any time (Moura, 2009, p.39). Educators are challenged today to search for teaching tools that can be used within the classroom as interactive methodologies that make the educational environment increasingly digital (Prensky, 2012). Gómez (2015, p.29) reinforces that "it is necessary to reinvent the school so that it can develop knowledge, skills, attitudes, values and emotions." The Unesco report (2014) presents the benefits that the use of mobile learning provides, among them we can facilitate individualized learning, provide immediate feedback and evaluation, ensure the productive use of time in the classroom, support learning outside the classroom to bridge the gap between formal and non-formal learning, to expand education in different places, to make it easier for students with disabilities, to enable learning anywhere and at any time, to build different learning communities and to improve communication among students and between students and teacher. According to Sharples et. al., (2007) mobile learning does not replace formal education at all, it simply provides support within and outside the classroom for the conversations and interactions of everyday life. For Vavoula \& Sharples 2002, we learn through space as we take learning ideas and resources acquired in one place and apply or develop in another. We also learn through time, reviewing previously acquired knowledge, ideas and strategies in a completely different and broader context. When we move from topic to topic, we manage a variety of learning rather than following a unique curriculum. In this sense, it is important to investigate different requirements related to m-learning projects, to improve the development and analysis of them. Thus, this work analyzed some proposals regarding the requirements and principles found in the literature, such as: Parsons, Ryu \& Crenshaw (2007), Uden (2007), Koole (2009), Peng, Su, Chou and Tsai (2011), Schmitz, Klemke, \& Specht (2012), Abdullah, Hussin, Asra, \& Zakaria (2013), Ng \& Nicholas (2013), Taylor, Sharples, O'Malley, Vavoula, \& Waycott (2004), Zurita \& Nussbaum (2007), Huang, Lin, \& Chuang (2007), Yau \& Joy (2010), Chang, Yan \& Tseng Sharples (2009), Sha, Looi, Chen and Zhang (2012), Herrington, Herrington \& Mantei (2009) and Churchill, Fox \& King (2016).

\section{MeTHOdOLOGY}

This work is based on a rigorous synthesis of all related research in a particular issue. It is different from the traditional one, since it uses a rigid methodology of search and selection of researches; 
analyzes the legitimacy of what was found; collects, synthesizes, and interprets data from investigations (Rother, 2007). In order to select research related to the central scope of this study, it was admitted the scientific survey in the thesis and periodicals database of the Coordination of Improvement of Higher Level Personnel, searching for the articles considered most important by specialists in their field of activity. In a first step, the keywords "requirements for mobile learning" were defined for search criteria, with only peer-reviewed articles being used. In the second stage, a filtering with the same criteria for the selection of national and international theses and dissertations was carried out, in order to collect more information about the topic. At the outset, the journals pertaining to the main issue were pre-selected by reading their titles, abstracts and keywords. Then all the pre-selected were evaluated and each of them was identified as the keywords were revealed, applied and worked out. Then, the data from the studies provided answers to the question from this review. Searches that were in more than one database were removed to avoid duplication. Finally, the data collected were synthesized to present the results.

\section{REQUIREMENTS AND PRINCIPLES FOUND IN THE LITERATURE}

Table 1 presents the main requirements and principles found in the literature related to m-learning projects.

Table1. Mobile Learning Models and Frameworks, Adapted From Hsu \& Ching (2015)

\begin{tabular}{|c|c|}
\hline Author & Proposed Framework or Framework \\
\hline Koole (2009) & $\begin{array}{l}\text { Framework Rational Analysis of Mobile Education (FRAME) } \\
\text { based on three fundamental components of mobile learning: } \\
\text { device, student and social }\end{array}$ \\
\hline Peng, Su, Chou e Tsai (2009) & Omnipresent conceptual framework of knowledge \\
\hline Park (2011) & Transactional distance theory framework \\
\hline Schmitz, Klemke, \& Specht (2012) & Conceptual framework to analyze the results of learning games \\
\hline Abdullah, Hussin, Asra, \& Zakaria (2013) & Framework with focus on language learning \\
\hline Ng \& Nicholas (2013) & Person-centered framework for sustainable learning in schools \\
\hline $\begin{array}{l}\text { Taylor, Sharples, O'Malley, Vavoula, \& } \\
\text { Waycott (2006) }\end{array}$ & Working model for mobile learning \\
\hline Motiwalla (2007) & $\begin{array}{l}\text { Framework for developing applications for collaborative } \\
\text { learning }\end{array}$ \\
\hline Parsons, Ryu, \& Cranshaw (2007) & Requirements framework for mobile learning environments \\
\hline Uden (2007) & $\begin{array}{l}\text { Framework that uses the Theory of Activity for Mobile } \\
\text { Learning }\end{array}$ \\
\hline Zurita \& Nussbaum (2007) & $\begin{array}{l}\text { Framework MCSCL (based on Engedrom's Expanded and } \\
\text { Activity Theory Model) }\end{array}$ \\
\hline Huang, Lin, \& Chuang (2007) & $\begin{array}{l}\text { Acceptance Model (Framework / model proposed in the } \\
\text { context of mobile learning that adds pleasure and mobility } \\
\text { value) }\end{array}$ \\
\hline Yau \& Joy $(2010)$ & Mobile learning model \\
\hline Chang, Yan, \& Tseng (2012) & $\begin{array}{l}\text { Acceptance Model (in the context of mobile learning adding } \\
\text { perceived convenience) }\end{array}$ \\
\hline Park, Nam, \& Cha (2012) & Student Acceptable Model for Mobile Devices \\
\hline Vavoula \& Sharples (2009) & 3-level Mobile Learning Assessment Framework \\
\hline Sha, Looi, Chen e Zhang (2012) & Learning model (SRL) of the mobile phone \\
\hline Herrington, Herrington \& Mantei (2009) & Principles of design for m-learning in higher education \\
\hline Churchill, Fox \& King (2016) & $\begin{array}{l}\text { Framework that addresses practical aspects of the context of } \\
\text { teachers considering the pedagogical use of mobile technology }\end{array}$ \\
\hline
\end{tabular}

Next, each of the proposed Model or Framework was detailed, aiming to identify gaps in the literature in order to provide future directions for research on mobile learning.

\subsection{Peng, Su, Chou e Tsai}

Peng, Su, Chou, and Tsai (2009) propose a ubiquitous conceptual framework of knowledge. Knowledge can be anywhere, including moving with mobile devices. It consists of a hierarchical structure with 1) mobile learners and ubiquitous computing tools that serve as a foundation (digital educational divide, classroom management, network literacy, and building partnerships for pedagogically sound educational tools); 2) pedagogical methods with a focus on constructivism and 
lifelong learning; and 3) vision on how to attain a ubiquitous construction of knowledge. This discussed the ubiquitous learning issues that need to be addressed in order to reach out and expand the ubiquitous knowledge building for mobile learning.

\subsection{Park}

Park (2011) created the transactional distance theory framework, dividing mobile learning into four types, which includes: 1) socialized m-learning of high transactional distance; 2) individualized transactional high-distance m-learning; 3) socialized transactional low-distance m-learning; and 4) individualized transactional low-distance m-learning. These four types of learning are mediated by mobile devices, with the goal of helping instructors.

\subsection{Schmitz, Klemke e Specht}

Schmitz, Klemke and Specht (2012) propose a conceptual framework to analyze the results of learning games. This is formed by two components: 1) the mobile game design standards established by Davidsson, Peitz, and Björk (2004); and (2) Bloom's (1956) taxonomy on learning outcomes involving affective domain and cognitive domain to analyze learning games on mobile devices.

\subsection{Abdullah, Hussin, Asra e Zakaria}

Abdullah, Hussin, Asra and Zakaria (2013) propose a framework focused on language learning. Its goal is to enable students to take advantage of mobile technologies with the help of those who have the most skills. The proposed adapted framework includes five stages: 1) access and motivation; 2) socialization of the network; 3) exchange of information; 4) context and knowledge construction; and 5) development. Its framework did not present an innovative structure, but it did highlight the unique aspects provided by mobile technologies and mobile learning. These unique aspects are 1) network and connectivity between mobile devices, systems, applications and people; and 2) mobility and the corresponding changing learning of contexts. The most capable (adults or peers) can and should help learners.

\subsection{Ng e Nicholas}

$\mathrm{Ng}$ and Nicholas (2013) propose a person-centered framework for sustainable learning in schools. It has a holistic view on how to ensure mobile learning, making stakeholders work together in an inclusive and communicative way. They argued that teachers are central to the success and sustainability of mobile learning. There are other stakeholders who are also important as: directors, coordinators, parents, students, technicians and community. Non-personal components include pedagogy, mobile devices, infrastructure, and interactions between stakeholders. They argued that the following aspects need to be addressed for a sustainable and successful mobile learning program: developing positive attitudes toward students in the program, providing sufficient technologies (hardware and software) and real-time technical support, ensuring stakeholder communication, especially with regard to consultation and feedback to avoid growing tensions and misunderstandings, delegating responsibilities with the trust of the management team to teachers as well as teachers to students. Trust will help members open up and be willing to communicate. In addition, all stakeholders need to develop a sense of ownership of the mobile learning program.

\subsection{Taylor, Sharples, O'Malley e Vavoula}

Taylor, Sharples, O'Malley and Vavoula (2006) propose a work model for mobile learning, which synthesized theoretical approaches that included sociocultural theory (Vygotsky, 1978), system of activity / theory (Engeström, 1987) and theory of conversation (Pask, 1976). The model has adapted the three components of Engeström: control (prior rules), context (previously community) and communication (formerly division of labor), which opens the way to add layers of spaces to help capture the complicated dynamics of mobile learning activities. The contribution of the model is to add the layers of technological space (communication protocol) and semiotic space (social rules), and emphasize the conversational / dialectical relationship between these two spaces. The task model also includes examples of each component and the spaces in the context of mobile learning systems. It can be useful for evaluating, modifying or creating mobile learning systems.

\subsection{Motiwalla}

Motiwalla (2007) discussed his experience of transforming e-learning into mobile learning by harnessing wireless connectivity and mobile devices. Its structure consists of requirements that must 
be considered when developing mobile applications to complement classroom or distance learning. He proposed a relatively simple framework to address the technical capabilities that enable content delivery, customization, and collaboration in mobile learning. In the content delivery dimension, pedagogical agents and mentors need to be able to take the learning materials or information to the students. Students need to be able to get the information they need (scheduling, notes, learning content, etc.) to their devices. On the other hand, the m-learning system needs to be able to support both personalized learning (alert assignment) and collaborative learning (chat room, discussion board, instant messaging, etc.).

\subsection{Parsons, Ryu e Crenshaw}

Parsons, Ryu and Cranshaw (2007) propose a requirements framework for mobile learning environments. Its model is divided into four perspectives: 1) generic issues of the mobile environment (role and user profile, mobility, mobile interface design, media types, communication support); 2) learning contexts (identity, student, activity, spatial-temporal, mobile devices, collaboration); 3) learning experiences (organized tasks, results and feedback, goals and objectives, representation or history, conflict, competition, challenge, opposition, social interaction); and 4) learning objectives (expanded skills, new skills, social and team skills). This structure also incorporated the interaction dimension that examines the different needs of individual and collective learning. Compared to the Motiwalla framework (2007), this framework is more sophisticated and comprehensive because it included and discussed more factors and subcomponents of each factor.

\subsection{Uden}

Uden (2007) proposed a framework for a mobile application that supports conscious and contextual learning. This structure is based on Engeström's Theory of Activity (TA) (1987). Uden argued that TA had advantages to substantiate the use of mobile applications in learning because it recognized the importance of various components and the interaction of those components that make learning (mobile) and successful learning possible. These topics include (students), objects (developed artifacts), goals (learning gain reflected in performance or test results), and tools. Tools, such as computers or mobile devices, can help mediate activities between the participants themselves (communication) and between subjects and objects (achieving the desired learning outcomes). The subjects also interact directly with the tools through the user interface of the tools (mobile devices). It is worth noting that with the emergence of mobile computers and technologies, tools can be integrated (chat / text and video communication via mobile devices) and become even more powerful in mediation. It is a very complete methodology, which addresses issues related to technology, social interactions, organization and development of activities, considering TA as theoretical support for the $\mathrm{m}$-learning project. This methodology seeks to: clarify the purpose of the activity, establish a system of collective activity, giving context and meaning to seemingly random and individual events, make clear the relevant context in which activities occur, analyze the activity system, using activity diagram of Engestrom, analyze the structure of the activity, externalization / internalization of activities and analyze potential primary and secondary contradictions in the scope of m-learning.

\subsection{Koole}

Koole (2009) proposed a framework that is intuitive and easy to apply. The Koole framework provides a practical checklist to assist educators in mobile learning. Koole's Rational Analysis of Mobile Education (FRAME) is based on three fundamental components of mobile learning: device, student and social. Koole pointed out that the intersection of the components include: device usability (device + student), technology (device + social) and interaction in learning (student + social). The FRAME model provides an intuitive and concise way to consider and design mobile learning activities. This model can be used: in the development of mobile devices, in the elaboration of learning materials and in the conception of teaching and learning strategies in the context of $\mathrm{m}$ learning. The device aspect refers to the physical, technical and functional characteristics of a mobile device. The student aspect, considers cognitive ability, memory, prior knowledge, emotions and motivations. The social aspect considers the processes of social interaction and cooperation, communication, exchange of information, acquisition of knowledge and cultural practices. The Device / Student aspect, contains usability attributes such as comfort and user satisfaction, access to information and mobility. The Device / Social aspect concerns social technologies, describing how mobile devices enable communication and collaboration. The Student / Social aspect presents the 
interactions in learning, with the theory or theories of learning adopted, emphasizing social constructivism. The Device / Student / Social aspect is the main intersection, which allows students to evaluate and select relevant information, define their objectives and reconsider their understanding of concepts, given the context of increasing and changing information, being constantly reformulated by the interaction between the three aspects of the model.

\subsection{Herrington, Herrington e Mantei}

Herrington, Herrington \& Mantei (2009) propose design principles for m-learning in higher education, based on the analysis of the articles in the book "New Technologies, New Pedagogies: Mobile Learning in Higher Education" Herrington et. al. (2009). The principles include: working with authentic situations, exploiting the potential of devices in contexts in which students are moving, enabling the exploitation of the resources of obile technologies, merging mobile and non-mobile technologies, using m-learning to mediate the construction of knowledge, encourage the spontaneous use of mobile devices, use m-learning in non-traditional learning spaces, promote individual and collaborative activities, employ the students' own mobile devices whenever possible, encourage the search, production and sharing of meaningful and understand and exploit mobile technologies. These principles are recommendations, which may be useful in designing m-learning activities in higher education, but which, by being very general, can be adapted without difficulty in other contexts.

\subsection{Churchill, Fox \& King}

Churchill, Fox \& King (2016) propose a framework that addresses practical aspects of the context of teachers considering the pedagogical use of mobile technology. Previous studies have pointed to different models for implementing mobile technologies in educational settings. However, few of them recognize the specific reality of an educational environment and the difficulties that must be assumed by teachers in the design and implementation of mobile education. Three different ways of integrating mobile devices into the teaching-learning processes were introduced. The first is to do so in support of the ongoing process developed by the teacher, including new communication channels. The second concerns its use as a source of the ongoing process developed by the teacher's activities, which may not be done in the classroom by the students, and which provide the supply of their educational processes. The third and last is to incorporate a new learning strategy in such a way that the teacher innovates his teaching practice. The framework is divided into six stages: Recognition (m-learning resources, Users and functions, Technical and development resources, Communication process), Analysis (Benefits of m-learning, Inclusion Scenarios, Educational Practice Analysis, Pedagogical Innovation ), Identification (Supply, Support, New Educational Experience, Incentive, Feedback Processes), Bases (Coherence with Established Pedagogical Bases, New Experiences, Learning Objective, Context Characteristics, Pedagogical Approaches), Design (Cognitive Processes, Context Functions , Content, Functions, Device Functionality, Objectives, Feedback, Interaction) and Implementation (Context Resources, Required Products, Device Features, Educational Resources, Evaluation). Each of them was designed as part of a process to be followed by the teacher and / or tutor to create effective strategies for mobile integration. This process mainly aims to respond to their educational context needs.

\section{FinAl CONSIDERATIONS}

Due to this lack, this research had the objective of reviewing the literature on requirements for mobile learning activities, aiming to identify gaps in the literature in order to provide future directions for research on this subject. Thus, this work addresses the main requirements and principles found in the literature related to m-learning projects.

This study contributes to demonstrate, based on the literature review: the main aspects and attributes of m-learning, the needs for the establishment and evaluation of m-learning, the possibilities and potential of m-learning for the teaching and learning processes. The identified and mapped criteria can help teachers and other professionals to use m-learning more effectively in the educational context.

\section{REFERENCES}

[1] Abdullah, M.R. T.L., Hussin, Z., Asra, \& Zakaria, A.R. (2013). Mlearning scaffolding model for undergraduate English language learning: Bridging formal and informal learning. The Turkish Online Journal of Educational Technology, 12 (2), 217-233.

[2] Bloom, B. S. (1956). Taxonomy of educational objectives, handbook 1: Cognitive domain. New York, NY: David McKay. 
[3] Chang, C. C., Yan, C. S., \& Tseng, J. S. (2012). Perceived convenience in an extended technology acceptance model: Mobile technology and English learning for college students. Australasian Journal of Education Technology, 28 (5), 809- 826. Retrieved from http://www.ascilite.org.au/ajet/

[4] Churchill, D., Fox, B., \& King, M. (2016). Framework for designing mobile learning environments. In D. Churchill, J. Lu, TKF Chiu, \& B. Fox (Eds.). Mobile Learning Design: Theories and Application. (pp. 326). New York: Springer.

[5] Davidsson, O., Peitz, J., \& Björk, S. (2004). Game design patterns for mobile games. Project report to Nokia Research Center, Finland. Retrieved from http://web.science.mq.edu.au/ isvr/Documents/ pdf\%20files/gamemaster/Game_Design_Patterns_for_Mobile_Games.pdf

[6] Engeström, Y. (1987). Learning by expanding: An activity-theoretical approach to developmental research. Helsinki, Finland: Orienta-Konsultit.

[7] Gómez, A. (2015). Perez. Education in the digital age - the educational school. Porto Alegre: I think.

[8] Herrington, A., Herrington, J., \& Mantei, J. (2009). Design principles for mobile learning. In J. Herrington, A. Herrington, J. Mantei, I. Olney, \& B. Ferry (Eds.), New Technologies, New Pedagogies: Mobile Learning In Higher Education (pp. 129-138). Wollongong: University of Wollongong. Retrieved from http://ro.uow.edu.au/

[9] Hsu, Y. C., \& Ching, Y. H. (2015). A review of models and frameworks for designing mobile learning experiences and environments. Canadian Journal of Learning and Technology, 41 (3), 1-22. https://doi.org/10.21432/t2v616

[10] Huang, J. H., Lin, Y. R., \& Chuang, S. T. (2007). Elucidating user behavior of mobile learning: A perspective of the extended technology acceptance model. The Electronic Library, 25 (5), 586-99. doi: 10.1108 / 02640470710829569

[11] Koole, M. L. (2009). A model for framing mobile learning. In M. Ally (Ed.), Mobile learning: Transforming the delivery of education and training (pp. 25-47). Edmonton, Canada: AU Press.

[12] Motiwalla, L. F. (2007). Mobile learning: A framework and evaluation. Computers \& Education, 49 (3), 581-596. doi: 10.1016/ j.compedu.2005.10.011

[13] Moura, A. (2009). Mobile Generation: a learning environment supported by mobile technologies for the "Generation Thumb", Emerging Environments, VI International Conference on ICT in Education, p. 4977.

[14] Ng, W., \& Nicholas, H. (2013). The framework for sustainable mobile learning in schools. British Journal of Educational Technology, 44 (5), 695-715. doi: 10.1111 / j.1467-8535.2012.01359.x

[15] Park, S. Y., Nam, M. W., \& Cha, S.B. (2012). University students' behavioral intention to use mobile learning: Evaluating the technology acceptance model. British Journal of Educational Technology, 43 (4), 592-605. doi: 10.1111/j.1467-8535.2011.01229.x

[16] Park, Y. (2011). A pedagogical framework for mobile learning: Categorizing educational applications of mobile technologies into four types. International Review of Research in Open and Distance Learning, 12 (2), 78-102. Retrieved from http://www.irrodl.org/index.php/irrodl/article/view/791/1699

[17] Parsons, D., Ryu, H., \& Cranshaw, M. (2007). A design requirements framework for mobile learning environments. Journal of Computers, 2 (4), 1-8. doi: 10.4304 / jcp.2.4.1-8

[18] Pask, G. (1976). Conversational techniques in the study and practice of education. British Journal of Educational Psychology, 46, 12-25. doi: 10.1111 / j.2044- 8279.1976.tb02981.x

[19] Peng, H., Su, Y., Chou, C., \& Tsai, C. (2009). Ubiquitous knowledge construction: Mobile learning redefined and a conceptual framework. Innovations in Education and Teaching International, 46 (2), 171183. doi: 10.1080 / 14703290902843828

[20] Prensky, M. (2012). Learning based on digital games. São Paulo: Senac.

[21] Rother, E. T. (2007). Systematic review versus narrative review. Acta Paulista de Enfermagem, v. 20, n. 2, p. V-VI.

[22] Schmitz, B, Klemke, R., \& Specht, M. (2012). Effects of mobile gaming patterns on learning outcomes: A literature review. International Journal of Technology Enhanced Learning, 4 (5-6), 345-358. doi: 10.1504 / IJTEL.2012.051817

[23] Sha, L., Looi, C.-K., Chen, W., \& Zhang, B.H. (2012). Understanding mobile learning from the perspective of self-regulated learning. Journal of Computer Assisted Learning, 28 (4), 366-378. doi: 10.1111/ j.1365-2729.2011.00461.x

[24] Sharples, M .; Taylor, J ; Vavoula, G. N. (2007). A Theory of Learning for the Mobile Age. In R. Andrews and C. Haythornthwaite (eds.) The Sage Handbook of Elearning Research. London: Sage, pp.221-247. 
[25] Taylor, J., Sharples, M., O'Malley, C., Vavoula, G. N., \& Waycott, J. (2006). Towards a task model for mobile learning: A dialectical approach. International Journal of Learning Technology, 2 (2/3), 138-158. doi: 10.1504 / IJLT.2006.010616

[26] Uden, L. (2007). Activity theory for designing mobile learning. International Journal of Mobile Learning and Organization, 1 (1), 81-102. doi: 10.1504 / IJMLO.2007.011190

[27] Unesco (2014). Policy guidelines for mobile learning. United Nations Educational, Scientific and Cultural Organization (UNESCO), France.

[28] Vavoula, G. N., \& Sharples, M. (2002). KLeOS: A personal, mobile, Knowledge and Learning Organization System. In Milrad, M., Hoppe, U. Kinshuk (eds.) Proceedings of the IEEE International Workshop on Mobile and Wireless Technologies in Education (WMTE2002), Aug 29-30, Vaxjo, Sweden, pp. 152-156.

[29] Vavoula, G. N., \& Sharples, M. (2009). Meeting the challenges in evaluating mobile learning: A 3- level evaluation framework. International Journal of Mobile and Blended Learning, 1 (2), 54-75. doi: 10.4018 / jmbl.2009040104

[30] Vygotsky, L. S. (1978). Mind in society: The development of higher psychological processes. Cambridge, MA: Harvard University Press.

[31] Yau, J. Y.-K., \& Joy, M. S. (2010). Proposal of a mobile learning preferences model. International Journal of Interactive Mobile Teaching, 4 (4), 49-51. Retrieved from http://online-journals.org/ijim/article/view/1445

[32] Zurita, G., \& Nussbaum, M. (2007). A conceptual framework based on activity theory for mobile CSCL. British Journal of Educational Technology, 38 (2), 211-235. doi: 10.1111 / j.1467-8535.2006.00580.x

\section{AUTHORS' BIOGRAPHY}

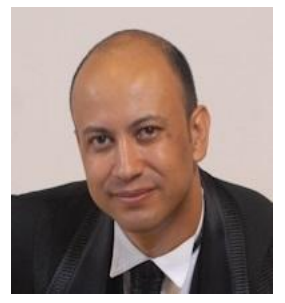

Ernane Rosa Martins, $\mathrm{PhD}$ in progress in Information Science with emphasis on Systems, Technologies and Information Management, at the Fernando Pessoa University, in Porto / Portugal. (2009), Graduation in Computer Science by Anhanguera (2006) and Graduation in Information Systems by the Uni Evangelical (2009). He has a postgraduate degree in Information Management Technology by Anhanguera (2009) He is currently Professor of Informatics II at the Federal Institute of Education, Science and Technology of Goiás - IFG (Campus Luziânia) providing courses in Software Engineering, Systems Development, Programming Languages, Database and Information Technology Management.

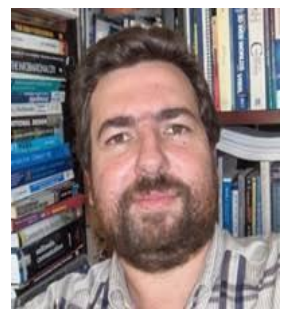

Luís Borges Gouveia, Degree in Applied Mathematics / Computer Science from the Portucalense University Infante D. Henrique (1989), Master's Degree in Electrical and Computer Engineering from the Faculty of Engineering of the University of Porto (1994) and $\mathrm{PhD}$ in Computer Science from the University of Lancaster (2002). He is currently an external examiner - University of East London and associate professor with the University of Fernando Pessoa. He has experience in Computer Science, with emphasis on Computer Science, working mainly in the following topics: information and communication technologies, information society, distance learning, information technologies and distance learning.

Citation: Ernane Rosa Martins, Luis Manuel Borges Gouveia. "Requirements for M-Learning Activities " International Journal of Humanities Social Sciences and Education (IJHSSE), vol 5, no. 11, 2018, pp. 1-7doi: http://dx.doi.org/10.20431/2349-0381.051101.

Copyright: (C) 2018 Authors. This is an open-access article distributed under the terms of the Creative Commons Attribution License, which permits unrestricted use, distribution, and reproduction in any medium, provided the original author and source are credited. 